Meta

Journal des traducteurs

Translators' Journal

\title{
Equivalence Parameters and Evaluation
}

\section{Heidrun Gerzymisch-Arbogast}

Volume 46, numéro 2, juin 2001

Évaluation : paramètres, méthodes, aspects pédagogiques /

Evaluation: Parameters, Methods, Pedagogical Aspects

URI : https://id.erudit.org/iderudit/002886ar

DOI : https://doi.org/10.7202/002886ar

Aller au sommaire du numéro

Éditeur(s)

Les Presses de l'Université de Montréal

ISSN

0026-0452 (imprimé)

1492-1421 (numérique)

Découvrir la revue

Citer cet article

Gerzymisch-Arbogast, H. (2001). Equivalence Parameters and Evaluation. Meta, 46(2), 227-242. https://doi.org/10.7202/002886ar

\section{Résumé de l'article}

Cet article traite du rôle des paramètres d'équivalence dans l'évaluation de traductions. Après un rapide survol des discussions inhérentes au concept même de l'équivalence, nous proposons d'examiner ce concept sur deux niveaux : celui du système à la base duquel les critères d'évaluation sont établis et, celui du texte qui permet la sélection des critères spécifiques pour évaluer le texte en question ainsi qu'une hiérarchisation de ces critères (du point de vue de l'évaluateur). Au niveau du système nous proposons d'inclure dans le catalogue des critères d'évaluation les paramètres de cohérence et de réseaux thématiques et/ou isotopiques. Au niveau du texte nous allons discuter quelques variances de traductions inhérentes à ces paramètres. 


\title{
Equivalence Parameters and Evaluation
}

\author{
HEIDRUN GERZYMISCH-ARBOGAST \\ University of Saarbrücken, Saarbrücken, Germany
}

\begin{abstract}
RÉSUMÉ
Cet article traite du rôle des paramètres d'équivalence dans l'évaluation de traductions. Après un rapide survol des discussions inhérentes au concept même de l'équivalence, nous proposons d'examiner ce concept sur deux niveaux: celui du système à la base duquel les critères d'évaluation sont établis et, celui du texte qui permet la sélection des critères spécifiques pour évaluer le texte en question ainsi qu'une hiérarchisation de ces critères (du point de vue de l'évaluateur). Au niveau du système nous proposons d'inclure dans le catalogue des critères d'évaluation les paramètres de cohérence et de réseaux thématiques et/ou isotopiques. Au niveau du texte nous allons discuter quelques variances de traductions inhérentes à ces paramètres.
\end{abstract}

\begin{abstract}
The article deals with the role of equivalence (parameters) in evaluating translated texts. After briefly portraying the controversy over the equivalence concept, it is proposed that this concept be considered on two levels: a system level on which Equivalence criteria are established and a text level on which a set of text-specific criteria is selected for evaluation purposes and the ranking of these criteria (from the evaluators point of view) with respect to their relevance in translating a particular text is made explicit. On a systems level it is suggested that the semantic network-based text and translation parameters of coherence, thematic and/or isotopic patterns be included in the catalogue of potential evaluation criteria. On a text level, possible motivations for translation variances in these parameters are discussed.
\end{abstract}

\section{MOTS-CLÉS/KEYWORDS}

equivalence parameters, evaluation, system level, text level, isotopic

\section{Introduction}

The following article deals with the parameters of coherence, thematic and isotopic patterns and their validity as equivalence parameters in evaluating translated ${ }^{1}$ texts. After briefly portraying the controversy over the equivalence concept, its value in comparing and evaluating translations is re-instated on two levels: a systems level on which equivalence criteria are established from different perspectives (itemized, relational and holistic pattern-forming) and a text level on which -for evaluation purposes- a set of criteria is selected to describe an individual text and the ranking of these criteria (from the evaluator's point of view) with respect to their relevance in translating a particular text is made explicit. On a systems level it is suggested that the semantic network-based text and translation parameters of coherence, thematic and/or isotopic patterns be included in the catalog of potential evaluation criteria. On a text level, possible motivations for translation variances in these parameters are discussed. 


\section{Equivalence and Equivalence Parameters}

\subsection{The Equivalence Controversy}

"Equivalence" is one of the most traditional and critical concepts in translation theory, being considered by some "constitutive for translation" (Koller 1997: 189) and the "nucleus of all translation theory" (Albrecht 1987: 13) and by others provoking contradicting opinions and carrying in its wake a plethora of definitions (Wilss 1977: 156). Adopted by translation theory in the fifties as a key term in machine translation, the notion of "Umkehrbarkeit" (equality) was its focus; later within human translation theory the focus shifted to "Gleichwertigkeit" (equatability) (Reiß 1971: 12). From a communicative point of view, Nida (1964: 159f) in the sixties distinguished between "formal equivalence" (referring to the relationship of ST and TT form and content elements) and "dynamic equivalence" (orienting itself towards the reader). Similar distinctions are made from a linguistic point of view by Catford (1978: 27ff) who distinguishes between "textual equivalence" and "formal correspondence" indicating two levels on which "equivalence" can be considered: a systematic, virtual level ("formal correspondence") and a parole-related, actual level ("textual equivalence"). Jäger (1975: 107) differentiates between "communicative equivalence" and "functional equivalence," already including theme-rheme patterns as an equivalence parameter. The most detailed concept of equivalence is presented by Koller (1997: 214ff), specifying five "equivalence frameworks": denotative, connotative, textnormative, pragmatic and formal equivalence. In the eighties and nineties, the equivalence concept was severely criticized for being too linguistically oriented (Snell-Hornby 1986: 13ff and others, cf. most recently Gallagher 1998) and even totally discarded as a valid concept for translation theory on the grounds that the concept suggested a symmetry between languages that did not exist. ${ }^{2}$ Subsequently, a variety of re-formulations and new standards were proposed (among others by Reiß/ Vermeer: 1984: 124), none of them solving the problem of conceptual specificity and explicitness. At the same time, however, new thoughts for a re-definition of the concept were formulated which no longer viewed "equivalence" as an overall encompassing concept (albeit possibly consisting of different layers or "frameworks") but as a concept relative to certain parameters which may vary by individual text (introducing de Beaugrande's text-linguistic features as equivalence parameters (Neubert 1985, Neubert/Shreve 1992) or Halliday's register-specific categories (House 1997)) or which may vary by so-called "Invarianzforderungen" (invariance postulates) to be negotiated between translator and the author of the original (Albrecht 1990).

\subsection{Equivalence as a Two-Tier Concept/on Two Levels}

This article follows this orientation and suggests that the "equivalence controversy" be dismissed as a misunderstanding of the equivalence concept as a result of the confusion created by using the term on two different linguistic levels:

- On a systems level, "EQUIVALENCE" as the (neutral) designation for parameters describing the relationship between a source and target text is indeed an indispensable, crucial term in translation theory since translation per se implies two sets of texts which need a standard of comparison. It has-on that level—nothing to do with an implied symmetry between languages which indeed would be trivial to assume. The 
parameters introduced by Neubert (1985), House (1997), Albrecht (1990) and others, are equivalence criteria on a systems level. It is here suggested to add to these the parameters of coherence, thematic, and isotopic patterns.

- On a text level, "equivalence" implies the application of these parameters to a specific concrete original and its translation and their evaluation as positive or negative "equivalence." The criteria for establishing positive or negative text-specific equivalence vary by text and need to be set for each text individually.

The two levels of equivalence can be illustrated by the following graph:

(1) Systems Level

EQUIVALENCE (= concept to depict the relationship between ST and TT, neutral in value, to be measured according to certain criteria or parameters)

(2) Text Level

Equivalence (= "equatability" of ST and TT)

Non-Equivalence (="non-equatability" of ST and TT, to be measured by a set of textspecific parameters for each instance of evaluation against the evaluator's individual ranking of these parameters according to their relevance for translation).

\section{The Systems Level: Some EQUIVALENCE Parameters Defined}

\subsection{Text and Translation Features in Perspective}

Before introducing network-based EQUIVALENCE parameters, we need to recognize that we can look at a text and describe its features (as ST for translation purposes) from different angles or perspectives which can also be applied to translation:

- An itemized perspective which looks at individual problems in a text and where we can identify local textual phenomena such as metaphors, clefting devices and/or ambiguities. In translation such problems are often dealt with locally in an ad hoc manner although it may be helpful to consider the overall distribution of such phenomena in the text with a view to invoking possible compensation strategies.

- A relational pattern perspective which describes patterns that have an identifiable beginning with subsequent identifiable elements in a text and where we can identify patterns with an identifiable starting point which are retraceable in their development over the whole text and which can be described as a sequence of individual phenomena. Examples are thematic and isotopic patterns (cf. 2.2.3 and 2.2.4). In translation it is necessary to develop a strategy for the whole pattern which then may influence local individual translation decisions.

- A holistic pattern perspective which encompasses holistic patterns as functional entities making up a text from which we can identify patterns in a text which have no identifiable starting point, the whole pattern being made up by elements that are functionally related to each other with one functional element being an element in a larger functional entity, which can make it hard to identify individual elements in a pattern (like the woods for the trees). Examples for holistic patterns are coherence, cultural and general or specific knowledge patterns. In translation we have to develop a strategy for the identification and translation for such patterns which may strongly influence local individual translation decision-making.

The following graph illustrates the three text and translation perspectives: 
FIGURE 1

Text and translation features in perspective

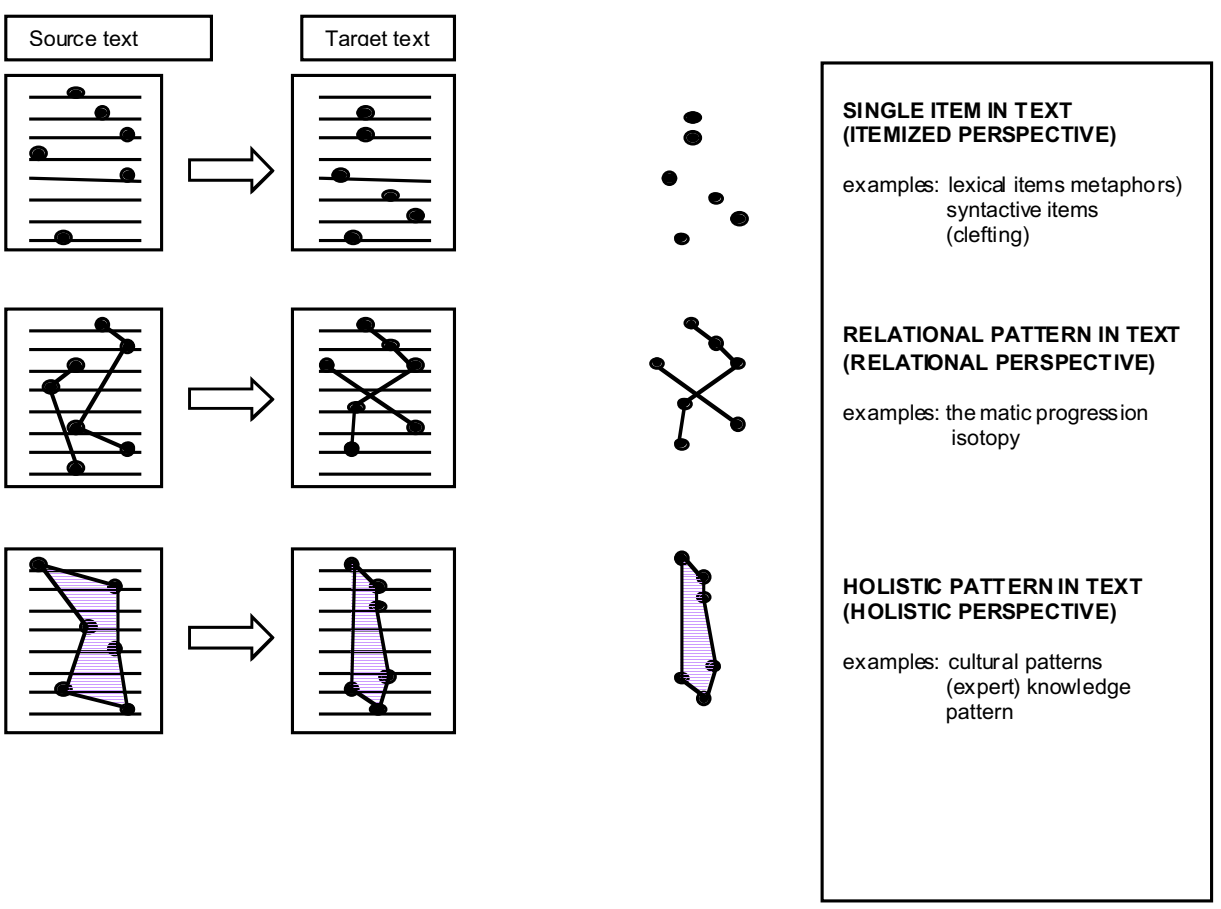

\subsection{Texts Represented as Semantic Networks ("Text Mapping")}

Distinguishing these text and translation perspectives for methodological reasons does not mean that they do not overlap in actual text analysis and translation as will be shown later using an example. First, however, we have to deal with the problem of how texts can be represented to allow for pattern identification and description for translation purposes. As has been shown elsewhere (Gerzymisch-Arbogast 1994, 1996; Gerzymisch-Arbogast und Mudersbach 1998; Gerzymisch-Arbogast 1999), we have worked with semantic networks as a representation and visualization tool. First developed in artificial intelligence (Quillian 1968, cf. also Schank 1975; Brachmann 1979; Sowa 1984), they were originally designed for meaning descriptions and knowledge representations in the form of graphs, the nodes representing concepts and the "Kanten" the relations existing between concepts. In linguistics two applications can be distinguished:

- description on a systems level, and

- description on a text level (Leinfellner 1992, Mehl 1993).

The first paradigm is primarily concerned with representing lexical knowledge as a conceptual hierarchy based on primarily paradigmatic relations (e.g. relations of synonymy, antonymy, hyponymy and part-of-relations) with blurred edges between linguistic and extra-linguistic knowledge. The second paradigm is concerned with making text comprehension accessible to description. The text is, or better, the relations in a text are represented and visualized as a semantic network (cf. de Beaugrande/ 
Dressler 1981). The semantic networks used for our purposes are based on the meaning and text theory of "leksemantics" (Mudersbach 1983), which proceeds from the basic idea that all factual information (information about objects and reality) in a text can be expressed in the form of relations. Relations consist of arguments (mostly nominal concepts) and relators (mostly verbs). The resulting textual network is fundamentally made up by arguments (graphically depicted as squares) and relators (graphically depicted as circles), with the arrow connecting these two elements indicating the agent position and/or goal or other semantic roles.

\subsubsection{Extracting networks from texts}

When extracting networks from texts, each sentence or text unit is classified according to whether the expressions contained in it are relators, i.e. verbs or verbal groups in need of complements, or whether they are arguments, i.e. nominal expressions. A relation representing a natural language utterance contains in its minimal structure at least one relator and at least one argument. Arguments directly related to the starting argument via a relator are classified as being on the first meaning level of the starting argument. In a further step it is possible to differentiate arguments which emanate from the end points of the first meaning level thus constituting a second meaning level. This procedure can be repeated until there are no further relations to which arguments can be connected (level (n)). The network levels represent the meaning levels of a concept and the level of conceptual differentiation of a text (cf. 2.2.4 isotopy). We can produce a network in which all relations connected with a particular concept in the text (and thus all information relating to that concept) are instantaneously (synchronously or synchrone-optically) visible. In a synchronous semantic network the linear structure of the text is given up. Networks are extracted from texts in a multi-step procedure (for further details cf. Gerzymisch-Arbogast 1994, 1996, Gerzymisch-Arbogast/Mudersbach 1998, Gerzymisch-Arbogast 1999), i.e.

1) segmentation of text in utterances

2) conversion of utterances into relations

FIGURE 2

\section{Conversion of a natural language utterance into a relation}

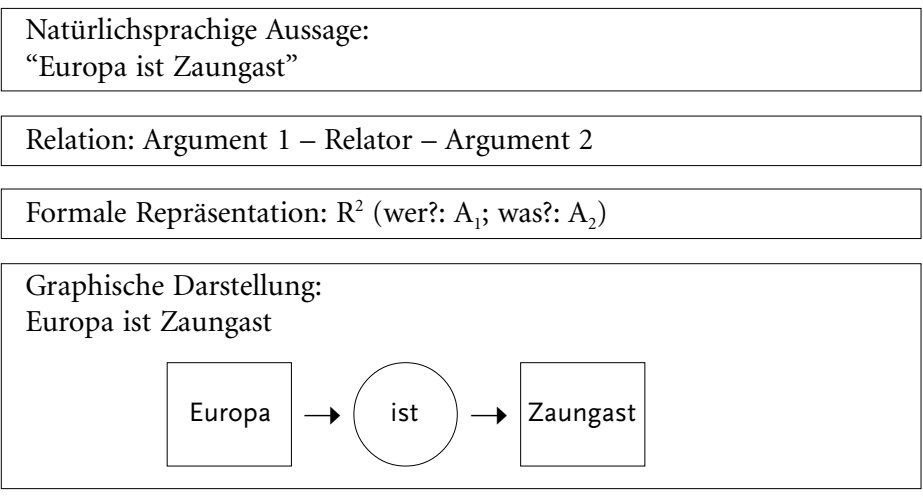

3) entering the relation into a computer data sheet

4) listing necessary hypotheses 
5) evaluation of relations and formation of network (with computer support)

6) graphic visualization

\subsubsection{Coherence}

Coherence may be represented as the connectivity of the relations in a text. Semantic networks ("text mapping") can help to visualize the coherence of texts. ${ }^{3}$ Not all relations can always be connected with other relations (cf. fig. 3). Unconnected arguments and relations form so-called "islands," which need individual (coherence building) hypotheses to be connected with the core network. The number of islands in a network represents its openness for reader interpretation, its degree of connectivity indicates its level of "coherence." Hypotheses are graphically represented by a dotted line to differentiate them from relations and to indicate that this is information not supplied in the text but by the individual reader.

Coherence is a relevant EQUIVALENCE parameter for translation purposes because it may differ in original and translated texts, for instance in the case of holistic cultural patterns when additional information needs to be supplied to adjust the translation to the target reader's expectations (cf. chapter 3 ).

\subsubsection{Text Topic and Thematic Patterns}

The representation of texts via semantic networks allows us to establish the text topic of a given text as the concept or argument in a text which encompasses (= binds) the highest number of relations.

Text topic and thematic patterns are relevant EQUIVALENCE parameters because we can now describe such text features as the number of topics in a text and whether the resulting pattern is text type-specific (e.g. thematic patterns in LSP texts vs. operative texts). For translation evaluation purposes we need to ask how the thematic pattern of the original differs from the translation and what the motivations for these differences are. It is one of the desiderata for translation theory to provide a systematic catalog of motivations for variations in ST/TT thematic patterns.

\subsubsection{Isotopic patterns}

Semantic networks also further help to identify isotopic patterns as relational patterns in a text (cf. 2.1) $)^{4}$. The idea of isotopy in Greimas' sense (Greimas ${ }^{2} 1986$ ) is to connect recurrent linguistic units or aspects by a line or thread. Different isotopic patterns can come close to one another or even interconnect in different sections of a text to form interwoven patterns. Methodologically, however, Greimas' isotopic lines are hard to analyze and isolate. ${ }^{5}$ On the basis of semantic networks this is easier and we can differentiate ${ }^{6}$ :

- a baseline isotopy for all concepts that occur more than once in a text;

- a first-degree isotopy which is established by taking the most frequently appearing concept in the text plus all end points of the relations connected with this concept (first meaning level);

- a second-level isotopy established by encompassing the relations of the second environment of the initial concept and so on until an end level (n) has been reached.

All first-degree and second-degree isotopic patterns that interconnect are consolidated to form one single isotopic pattern, i.e. the top-level isotopy of the whole text. 
As has been previously shown (Mudersbach/Gerzymisch-Arbogast 1989), the higher the isotopic level, the more initially independent isotopic patterns interconnect. This reflects the meaning continuity of the text at various levels. If the separate isotopic patterns do not fuse, this may be due to islands in the text, i.e. partial meaning networks which are not explicitly linked to the core meaning network(s). These result is coherence gaps, as in our example, which need to be closed by individual hypotheses if the text is to be made comprehensible.

In translation, isotopy helps to identify and isolate explicit and implicit meaning patterns of a source text which may remain more or less intact in a target text. It is thus a relevant EQUIVALENCE parameter for translation. The relevance of isotopy for translation has been shown (Gerzymisch-Arbogast 1994: 126) with respect to text analysis and comprehension and to its support as a monosemization tool and with respect to being considered a possible translation unit as illustrated in the example below.

\section{The Text Level: Some Equivalence Parameters Applied}

Text-specific equivalence includes a catalog of parameters selected for each evaluation instance. These may include theory-related criteria that the text under evaluation has in common with other texts of the same type but must also include ad hoc criteria which may be specific only to the particular text in question. Transparency must be secured with respect to (1) the criteria used to establish equivalence (e.g. in matrix form as in Gerzymisch-Arbogast 1994: 44) and (2) the evaluator's individual ranking of the criteria according to their relevance for the particular text under evaluation. Making the evaluator's judgement transparent with respect to the criteria used and his/her own ranking of these criteria is as much as we can expect in the sense of "objectivity" in evaluation. It makes it possible to discuss the validity of one evaluation against other evaluations on the basis of varying criteria and individual rankings with the possibility that the differences in these aspects can be made the object of discussion rather than polemic debates over the quality of a concrete isolated translation decision.

\subsection{Text and Translation Sample}

Having established the semantic network-based text and translation parameters of coherence, text topic and thematic as well as isotopic patterns, their relevance as evaluation criteria in translation can now be discussed using as an example the sample text below and its depicting semantic networks: 


\section{Sample Text (German Original):}

Europa kann es sich nicht leisten, Zaungast zu bleiben. (...) Europa muß daher eine positive Rolle übernehmen, um Herr seiner Zukunft zu bleiben. (...) Daß sie direkt unter Beschuß liegt, ist sich die Industrie schon seit längerer Zeit im klaren und hat sich bemüht, die Situation in den Griff zu bekommen. Die Kommission schlägt daher vor, die erste Fünfjahresphase des zehnjährigen Programmes Esprit (...) in Angriff zu nehmen.?
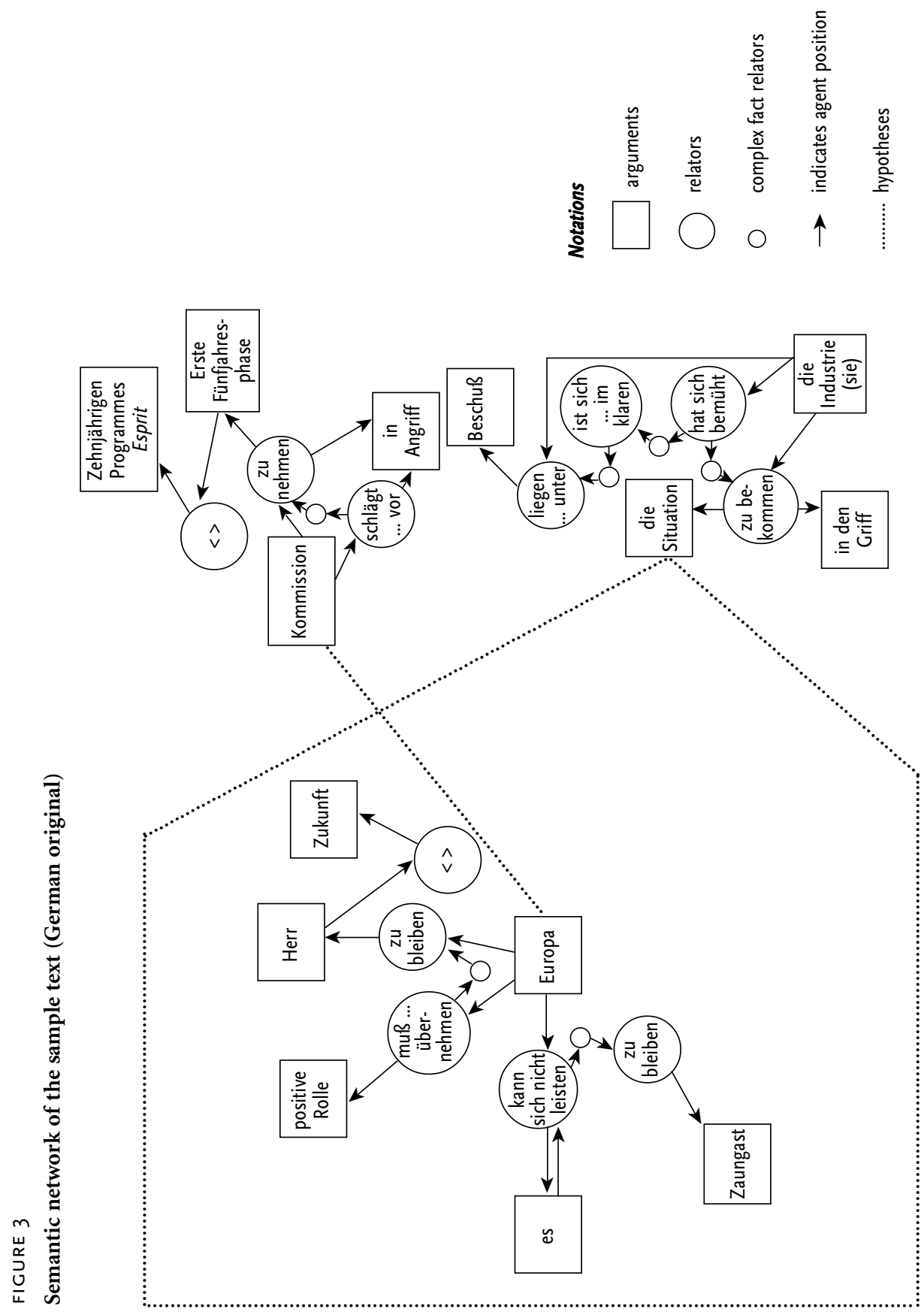


\section{English SYSTRAN Translation ${ }^{8}$}

Europe cannot afford it to remain fence guest. Europe must take over therefore a positive role, in order to remain master of its future. Since it is directly under bombardment, itself the industry is already for a long time in the clear and strove to get the situation in the grasp. The commission therefore suggests tackling the first five-yearly phase of the ten-year program Esprit.
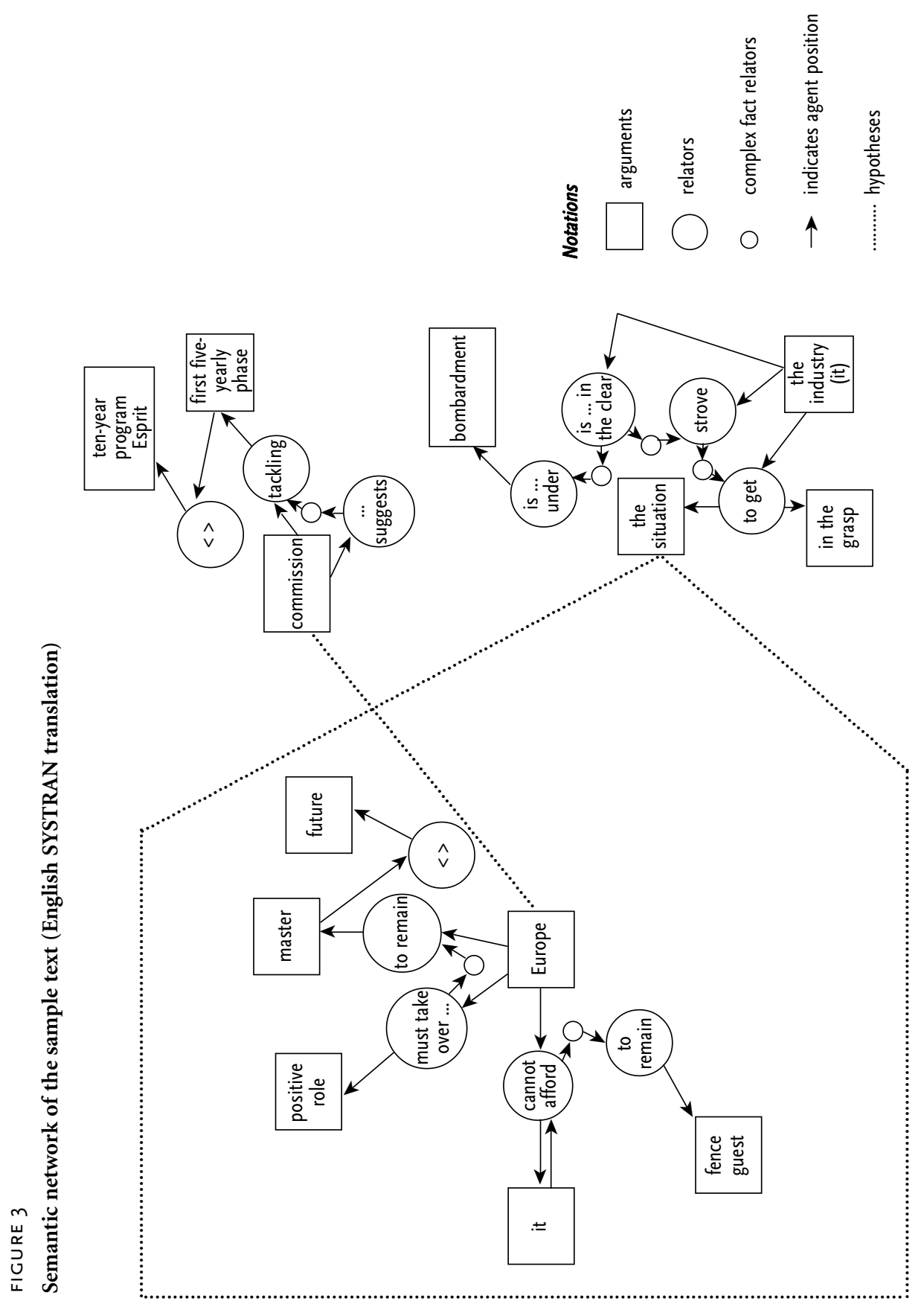


\subsubsection{The Equivalence Parameters Applied: Coherence}

The sample text above is "open" with coherence gaps (or non-coherent" relations) around the arguments "Situation" and "Kommission" making it necessary to form a (world knowledge) hypothesis between "Kommission" and "Europa" (the Commission as one of the organs of the European Union) and a (text-constitutive) hypothesis with the relation around "situation," anaphorically referring to what has been said in the previous sentences.

The lack of coherence in this text may reflect the fact that the text sample is a text excerpt with missing sentences.

The SYSTRAN translation keeps this lack of coherence invariant with the same coherence gaps around commission and situation, necessitating the same hypotheses as in the original.

\subsubsection{The Equivalence Parameters Applied: Text Topic and Thematic Patterns}

In our example, the concept that encompasses the greatest number of relations, i.e. the text topic, is "Europe," entering into two (complex) relations. Both "Situation" and "Kommission" each enter into only one (complex) relation and thus constitute only secondary (possibly tertiary) ${ }^{10}$ text topics.

The lack of coherence discussed previously is matched by a lack of density in the thematic pattern with three different topics in the four sentence paragraph. Again this may be due to the fact that the network represents a text excerpt with missing sentences.

The SYSTRAN translation keeps this lack of thematic density invariant with the same number of relations around "commission" and "situation," necessitating the same hypotheses as in the original.

\subsubsection{The Equivalence Parameters Applied: Isotopic Patterns}

In our example, the baseline isotopy is "Europa" (occurring twice, while the other concepts, "Situation" and "Kommission" only occur once). The first-level isotopy (= the first surrounding or meaning level around Europe) encompasses such concepts as

- Zaungast

- Herr (bleiben)

- Zukunft

- $\quad$ positive Rolle

- Kommission (per hypothesis)

The second-level isotopy is constituted by the first surrounding of "Kommission" as one of the end points of the first surrounding of "Europa" (being connected to "Europa" via a world knowledge hypothesis), encompassing such concepts as

- $\quad$ Angriff (nehmen, in)

- erste Fünfjahresphase

- zehnjähriges Programm

There is yet a "third-level isotopy" (if we consider "Situation" and the required hypothesis connecting it to the previous text on a second meaning level relative to "Europa") with 


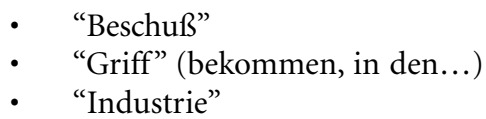

The lines do not interconnect (which may again be due to the fact that the sample is an excerpt with some sentences missing) so that no top-level isotopy can be established. However, on all isotopic levels we can find expressions of aggressiveness ((nicht) Zaungast (bleiben), Herr seiner Zukunft (bleiben), (in) Angriff (nehmen), (unter) Beschuß (liegen), (in den) Griff (bekommen)) ${ }^{11}$ which reflects a semantic continuity level in the sense of Greimas' isotopy concept.

The SYSTRAN translation does not keep the isotopic pattern invariant although it imitates the source text words and/or word order: Although the baseline isotopy "Europe" is intact and the first-level isotopy with "fence guest," "master" (remain), "future," "positive role," and "commission" (per hypothesis) is a mirror image of its source text counterpart although not as easily understandable as in the ST because of its unidiomatic expressions, the second-level isotopy has no matching expression for "Angriff" (nehmen, in) and thus lacks the element of "aggressiveness." The "thirdlevel isotopy" realizes "Beschuß" with the stronger "bombardment" and "Griff" (bekommen, in den...) with the weaker "grasp" while keeping "Industrie" as "industry." The isotopic ST pattern of "aggressiveness" is thus not kept invariant in the TT.

\subsection{The evaluation problem: Text-specific equivalence and parameter ranking}

Evaluating translations is one of the most discussed topics in translation theory ${ }^{12}$. As suggested in earlier publications (Gerzymisch-Arbogast 1994, 1995, 1996b, 1997, 2001 forthcoming), the desideratum of "objectivity" (which is probably unobtainable given people's preferences and the influence of stereotyped judgement on their decision-making ${ }^{13}$ ) should be replaced by the condition of "transparency" of the equivalence criteria, their consistent application (cf. especially Gerzymisch-Arbogast 1997) and of the evaluator's ranking of these criteria with respect to their relevance in the translation.

\subsubsection{Text-Specific Equivalence}

Text-specific equivalence if understood in the above-described sense as a parole-oriented standard (as EQUIVALENCE (2), cf. chapter 2) and as a concept relative to certain criteria selected and ranked specifically for each individual text (cf. Gerzymisch-Arbogast 1997) can certainly be considered as a valuable translation evaluation standard. Such criteria may include lexical, semantic, syntactic and pragmatic factors, and may be theory-based (e.g. House's register linguistic criteria (House 1997) or Neubert's text linguistic criteria (1985)) or may not be related to a particular (text) linguistic approach (e.g. Koller ${ }^{5} 1997$ ). But they need to be established for the purposes of evaluating the specific text under evaluation. Pre-determined formats (applicable to all or a great number of texts) will only yield those characteristics of texts asked for and listed in the format (and which are shared by a group of texts). Individual texts-although they may have certain features in common with other texts-owe part of their individuality to idiosyncratic ad hoc features which cannot be a priori standardized. These features are lost when using an a priori established format for text analysis. It has therefore been suggested to apply a 
modified Aspectra matrix for evaluation (cf. Gerzymisch-Arbogast 1994: 44) according to which relevant criteria (= aspects) of an individual text are established as evaluation criteria for a particular individual text. The above described semantic network-based parameters (coherence, text topic and thematic as well as isotopic patterns) are conceptually and methodologically strong enough to serve as reliably applicable text-based equivalence criteria. They are not proposed as exclusive universally relevant criteria but as possibly relevant among other relevant criteria which may be selected as equivalence criteria for an individual text.

\subsubsection{Parameter Ranking}

Translation evaluation will always contain a "subjective" element because evaluators have different preferences and make different judgements. However, these need to be made transparent as the evaluator's individual ranking of equivalence parameters according to their assumed or projected relevance in the target text. Such ranking judgements will largely depend on the purpose of the target text.

Taking our sample text and translation as an example, we can safely assume that the equivalence criteria of "lexis" (idiomatic expressions) and "syntax" (norm-conforming syntactical structures) would be given a higher ranking on the list of textspecific equivalence parameters than the parameters introduced above-if ST and TT are to be functionally equivalent as what can be called a working or rough translation. If, however, a coherent target text is to be produced, then the above parameters may well come into play, for instance-with respect to coherence-by rendering hypothetical relations into explicit relations or-if the target text is to be a summary or abstract - by deleting some of the secondary or tertiary topics. Depending on the intended quality of the target text, isotopic patterns may be requested to be maintained in which case this particular parameter may occupy a high position on the ranking list.

\subsection{Motivations for Parameter Variance and Invariance in Translation}

All equivalence criteria are subject to variance or invariance in translation depending on the purpose of the target text. It has often been suggested that coherence, text topic and thematic as well as isotopic patterns in texts are generally invariant in translation. This is, however, not necessarily so as we have seen with the isotopic variance in the above SYSTRAN translation which can be assumed to have not been intended. It is suggested that text-specific equivalence parameters can vary for at least four reasons: for language system-related, language norm-related, culture-specific and functional reasons. ${ }^{14}$

Language system-and norm-related variances may lead to variant isotopic patterns as we have seen in the above example where the isotopic pattern of "aggressiveness" is less strong in the translation: "Fence guest" is unusual in English, as is "remain master of its fate" or "directly under bombardment" in this context. It would have been possible to preserve these meaning potentials underlying the German phraseological units if the translation had been rendered by a human translator aware of the implicit isotopy in the source text (i.e. aggressiveness). This could have been effected by choosing a verbal phrase (e.g. "Europe cannot afford to keep sitting on the fence") or by choosing "remain master of its own fate" or "control its own future" instead of the unusual "remain master of its future" for "Herr seiner Zukunft bleiben." "Bombard- 
ment" (instead of "under attack") is too concrete an expression in this context and could hardly form an isotopic line with the weak and awkward "get the situation into the grasp" instead of "come to grips with" or "get a grip of the situation" for "in den Griff bekommen." "In Angriff nehmen" on the second level of isotopy would have needed a corresponding "aggressive" expression in English.

Culture-specific variances would have come into play if the text had to be translated for an American audience, in which case an explaining paraphrase might have been required for "Esprit program." Adding information to texts, however, always changes the text's coherence pattern in that it expands the text and thus the semantic network and possibly changes the explicitness of relations (hypotheses versus verbalized relations).

Finally, functional variation may result in variations with respect to all three parameters above. Reducing texts to summaries or abstracts always changes the coherence, thematic and/or isotopic patterns although the exact extent to which this occurs is not yet known. As an example, text reductions may lead to deletions of redundancies (in our above sample the possible deletion of the phraseological elements) and thus reductions in the continuity of isotopic patterns or deletions of less important information involving variances in the thematic structure and in the coherence pattern.

It is a desideratum for translation theory to research the correlation between parameter variance and text function and, on the basis of these findings, provide a catalog of variances motivated by changes in the text function. This would facilitate translation evaluation with respect to judging the legitimization of ST/TT variations.

\section{Summary and Perspectives}

After a brief account of the equivalence controversy, a two-level perspective of equivalence, i.e. EQUIVALENCE on a systems level and equivalence on a text level, was discussed. To make text-specific equivalence a valuable standard for evaluating translations, it was suggested that the concept needs to be relativized according to criteria or aspects on the basis of their relevance to the individual text under evaluation and their intended target text relevance. These criteria may include text features that are common to a number of texts (of a particular type) but should not exclude criteria formed ad hoc (if relevant) to describe the idiosyncracy of the individual text to be evaluated. Text-based parameters (coherence, text topic and thematic and isotopic patterns) based on the representation of texts as semantic networks were introduced, suggesting that they should be included in the catalog of possible criteria when establishing text-specific equivalence for evaluation purposes. To date it is largely maintained that coherence, text topic, thematic and isotopic patterns remain invariant in translation. With these parameters now methodologically easy to operationalize it becomes possible to investigate large corpora of texts and translations to determine whether this is indeed so or whether variances of a particular kind can be observed under differing TT conditions. This could lead to findings concerning the relevance of these network-based parameters in describing texts, establishing text-specific equivalence, and leading to possible classifications of translation variances in these parameters (for linguistic, cultural, functional norm-related or other reasons) and to the positioning of these variances within the framework of text-specific equivalence parameters in translation evaluation. 


\section{NOTES}

1. The same principles hold for interpreted texts (cf. Gerzymisch-Arbogast 2000b, Kusztor 2000).

2. Looking at the expression "equivalence" contrastively, i.e. contrasting its meaning across languages, does not appear to be useful, because such a procedure does not take note of the fact that we are looking at a technical term (not a general language expression), used internationally to designate a concept in translation theory, and as such-if we want to discuss its validity across language borders-is by nature universal (by Wüster's definition of a term).

3. The textlinguistic concept of coherence in its relation to translation is described in more detail in Gerzymisch-Arbogast $2000 \mathrm{~b}$.

4. For a more detailed description of the concept cf. Gerzymisch-Arbogast 1987, Mudersbach/ Gerzymisch-Arbogast 1989, Gerzymisch-Arbogast 1998).

5. For a detailed discussion cf. Mudersbach/Gerzymisch-Arbogast (1989).

6. The methodology of establishing isotopies on the basis of semantic networks is described in Mudersbach/ Gerzymisch-Arbogast (1989: 158f) and is thus not repeated here.

7. aus: Vorschlag für einen Beschluß des Rates zur Annahme des ersten europäischen strategischen Programms für Forschung und Entwicklung auf dem Gebiet der Informationstechnologie, Juni 1983, von der EG-Kommission dem Rat vorgelegt. Zitiert nach Rothkegel, Annely (1999): "Zur Metaphernfunktion von Phrasemen im Diskurs (Werbe- und Fachtexte)." In: Fernandez Bravo, n./ Behr, I./Rozier, C. (Hrsg): Phraseme und typisierte Rede. Tübingen: Stauffenburg. 91-100.

8. This machine translation was rendered by the online SYSTRAN translation service offered HEISOFT.

9. The expression un-coherent is used here to indicate that the text can be made coherent by an individual reader's interpretation. "Incoherent" is reserved for nonsensical contexts.

10. Classifying them as "secondary" or "tertiary" depends upon considering the status of "Situation" to be an independent or textually bound and thus dependent concept.

11. This is discussed as constituting the schema "competition" from the perspective of phrasemes and their metaphoric functions in Rothkegel (1999).

12. Different theoretical perspectives have been proposed, the most prominent being the approaches of Reiß (1971), Koller (1997) and House (1997).

13. For more detail cf. Wintermantel (1999).

14. This list is not intended to be representative but rather is a desideratum for translation research to develop a systematic catalog of variance motivations in correlation to TT purposes.

\section{REFERENCES}

Albrecht, J. (1987): "Wissenschaftstheoretischer Status und praktischer Nutzen der Übersetzungswissenschaft.” In: Ehnert, R./Schleyer, W. (Hrsg.) (1987): Übersetzen im Fremdsprachenunterricht. Beiträge zur Übersetzungswissenschaft-Annäherungen an eine Übersetzungsdidaktik. (=Materialien Deutsch als Fremdsprache 26). Regensburg. 9-23.

Albrecht, J. (1990): “Invarianz, Äquivalenz, Adäquatheit.” In: Arntz, P./Thome, G: (Hrsg.) (1990): Übersetzungswissenschaft: Ergebnisse und Perspektiven. Festschrift zum 65. Geburtstag von Wolfram Wilss. Tübingen: Narr. 71-81.

Beaugrande, R.-A. de/Dressler, W.U. (1981): Einführung in die Textlinguistik. Tübingen: Niemeyer.

Brachman, R. J. (1979): “On the episemological status of semantic networks." In: Findler, N. (Hrsg.) (1979): Associative networks. New York: Academic Press.

Catford, J. C. ( $\left.{ }^{5} 1978\right)$ : A Linguistic Theory of Translation. Oxford: University Press.

Fernandez Bravo, N./Behr, I./Rozier, C. (Hrsg.) (1999): Phraseme und typisierte Rede. Tübingen: Stauffenburg.

Gallagher, J. D. (1998): “Möglichkeiten und Grenzen der Übersetzungsäquivalenz.” In: Börner, W./Vogel, K. (Hrsg.) (1998): Kontrast und Äquivalenz: Beiträge zu Sprachvergleich und Übersetzung. Tübingen: Narr. 1-29.

Geко Kemuri (1995): "Übersetzungskritik - ein Würfelspiel? Einige Aspekte zur Entpolemisierung der Debatte um die Übersetzung von “Lempriere’s Wörterbuch” (Lawrence Norfolk).” Teamarbeit (unter dem Sammelnamen "Geko Kemuri”) von Heidrun Gerzymisch-Arbogast, Ingrid 
Koch-Dubbers, Regina Keil, Klaus Mudersbach, Ursula Rinne. In: Lebende Sprachen, XL. Jahrgang, Heft 1, 1995. S. 1-5.

Gerzymisch-Arbogast, H. (1987): Zur Thema-Rhema-Gliederung in amerikanischen Wirtschaftsfachtexten. Eine exemplarische Analyse. Tübingen: Narr.

Gerzymisch-Arbogast, H. (1994): Übersetzungswissenschaftliches Propädeutikum. Tübingen: Francke (UTB 1782).

Gerzymisch-Arbogast, H. (1995): “Übersetzungskritik—ein Würfelspiel?.” In: Haensch, Günther/Krollmann, Friedrich (Hrsg.) (1995): Lebende Sprachen 1/95, 1-5. (Zusammen mit Ingrid Koch-Dubbers, Regina Keil, Klaus Mudersbach, Ursula Rinne = GEKO KEMURI).

Gerzymisch-Arbogast, Heidrun (1996a): Termini im Kontext. Verfahren zur Erschließung und Übersetzung der textspezifischen Bedeutung von fachlichen Ausdrücken. Tübingen: Gunter Narr Verlag (FFF 31).

Gerzymisch-Arbogast, H. (1996b): "Holistic Evaluation Criteria for Translation Quality Assessment." In: Lauer, A. (Hrsg.) (1996): Perspectives on Translation Evaluation. Möglichkeiten der Übersetzungsevaluierung . Duisburg: L.A.U.D. (= Series B: Applied and Interdisciplinary Papers; Paper No 271). 9-39. (Zusammen mit Sabine Blum u. Claudia Mannsperger).

Gerzymisch-Arbogast, H. (1997): "Wissenschaftliche Grundlagen für die Evaluierung von Übersetzungsleistungen.” In: Fleischmann, E./Kutz, W./Schmitt, P. A. (Hrsg.) (1997): Translationsdidaktik: Grundfragen der Übersetzungswissenschaft. Tübingen: Narr. 573-579.

Gerzymisch-Arbogast, H. (1998): "Isotopien in Wirtschaftsfachtexten - ein Analysebeispiel." In: Hoffmann, L./Kalverkämper, H./Wiegand, H.E.. et. al. (Hrsg.): Handbücher zur Sprachund Kommunikationswissenschaft (HSK): Fachsprachen - Languages for Special Purposes. Ein internationales Handbuch zur Fachsprachenforschung und Terminologiewissenschaft. Berlin: de Gruyter. 595-602.

Gerzymisch-Arbogast, H. (1999): "Kohärenz und Übersetzung: Wissenssysteme, ihre Repräsentation und Konkretisierung in Original und Übersetzung." In: Gerzymisch-Arbogast, H./ Gile, D./House, J./Rothkegel, A. (Hrsg.) (1999): Wege der Übersetzungs- und Dolmetschforschung. DGÜD-Jahrbuch Übersetzen und Dolmetschen. Bd.1.Tübingen: Narr. 77-106.

Gerzymisch-Arbogast, H. (2000a): “Theme-Rheme Organization (TRO) and Translation.” In: Frank, A. P./Greiner, N./Hermans, T./Kittel, H./Koller, W./Lambert, J./Paul, F. (Hrsg.) (2000): Übersetzung-Translation-Traduction. Ein internationales Handbuch zur Übersetzungsforschung. Berlin: de Gruyter.

Gerzymisch-Arbogast, H. (2000b): “,Text-bound interpretation': Zum Aufschlußwert der Textdimension für die Dolmetschforschung." In: Schmitt, Peter A. (Hrsg.) (2000): Paradigmenwechsel der Translation. Festschrift für Albrecht Neubert zum 70. Geburtstag. Tübingen: Stauffenburg. (= Stauffenburg Festschriften). 101-119.

Gerzymisch-Arbogast, H./House, J./Koller, W. (Hrsg.) (2001): Modelle der Translationskritik. Tübingen: Narr. (= Jahrbuch Übersetzen und Dolmetschen. 2/2001). (erscheint)

Gerzymisch-Arbogast, H./Mudersbach, K. (1998): Methoden des wissenschaftlichen Übersetzens. Tübingen, Basel: Francke (UTB 1990).

Greimas, Algirdas J. ('1986/1966): Sémantique structurale. Recherche de méthode. Nouvelle ed. Paris: Presses Universitaires de France. (Strukturale Semantik). Aus dem Französischen übersetzt. Braunschweig: Viehweg.

House, J. (1997): Translation Quality Assessment. A Model Revisited. Tübingen: Narr.

JäGer, G. (1975): Translation und Translationslinguistik. (Linguistische Studien). Halle (Saale): Niemeyer.

KolLer, W. ( $\left.{ }^{5} 1997 / 1979\right)$ : Einführung in die Übersetzungswissenschaft. Wiesbaden: Quelle \& Meyer.

Kusztor, M. (2000): “Dastellung von Kohärenz in Original und Verdolmetschung.” In: Kalina, S./ Buhl, S./Gerzymisch-Arbogast, H. (Hrsg.) (2000): Dolmetschen: Theorie - Praxis - Didaktik - mit ausgewählten Beiträgen der Saarbrücker Symposien. Arbeitsberichte des Advanced Transaltion Research Center (ATRC) an der Universität des Saarlandes. Bd. 2. St. Ingbert: Röhrig. (im Druck) 
Leinfellner, E. (1992): Semantische Netze und Textzusammenhang. Frankfurt am Main: Peter Lang.

MenL, S. (1993): Dynamische semantische Netze. Zur Kontextabhängigkeit von Wortbedeutungen. Sankt Augustin: Infix.

Mudersbach, Klaus (1983): “Leksemantik - eine hol-atomistische Bedeutungstheorie." In: Conceptus XVII, Nr. 40/41, 1983, 139 - 151.

Mudersbach, Klaus (1988): "Die Methode der Gesetzesanalyse als Beitrag der IndividualLinguistik zur Erfassung der Patienten-Wirklichkeit." In: Zeitschrift für Literaturwissenschaft und Linguistik 69, 1988, 84-110.

Mudersbach, Klaus (1991): “Erschließung historischer Texte mithilfe linguistischer Methoden.” In: Best, H. und Thome, H. (Hrsg.): Neue Methoden der Analyse historischer Daten. Reihe "Historisch-Sozialwissenschaftliche Forschungen," Band 23, St. Katharinen, Scripta Mercaturae Verlag, 318-362.

Mudersbach, Klaus/Jacob, Wolfgang/Schönherr, Lutz (1988): “The network of law-like knowledge of an ill person, obtained from his utterances." In: Communication \& Cognition, Vol. 22, Nr. 2, 177-190.

Mudersbach, Klaus/Koch, Heinz Detlef (1988): "Eine Methode des wissenschaftlichen Übersetzens (mit Computerunterstützung).” In: B. Spillner (Hrsg.): Angewandte Linguistik und Computer. Kongreßbeiträge der 18. Jahrestagung der Gesellschaft für Angewandte Linguistik GAL, Tübingen, 67-68.

Mudersbach, Klaus/Gerzymisch-Arbogast, Heidrun (1989): “Isotopy and Translation.” In: Krawutschke, P.W. (Hrsg.): Translator and Interpreter Training and Foreign Language Pedagogy. American Translators Association Scholarly Monograph Series. Vol. III. Binghamton: State University of New York at Binghamton. 147-170.

Neubert, A. (1985): Text und Translation. Leipzig: Enzyklopädie.

Neubert, A./Shreve, G. M. (1992): Translation as Text. Kent, Ohio: The Kent State University Press.

NidA, E. A. (1964): Toward a Science of Translating. Leiden: Brill.

Quillian, M. R. (1968): “Semantic memory.” In: Minsky, M. (Hrsg.) (1968): Semantic information processing. Cambridge, MA: MIT Press. 227-270.

ReIss, K. (1971): Möglichkeiten und Grenzen der Übersetzungskritik. Kategorien und Kriterien für eine sachgerechte Beurteilung von Übersetzungen. München: Hueber.

Reiss, K./Vermeer, H. J. (1984): Grundlegung einer allgemeinen Translationstheorie. Tübingen: Niemeyer.

Rothkegel, A. (1999): "Zur Metaphernfunktion von Phrasemen im Diskurs (Werbe- und Fachtexte)." In: Fernandez Bravo, N./Behr, I./Rozier, C. (Hrsg.) (1999). 91-100.

Schank, R. C. (1975): Conceptual Information Processing. Amsterdam: North Holland Publ. Comp.

SCHÖNHERR, Lutz/Mudersbach, Klaus (1992): "RELATAN - Computer-aided Analysis of Texts based on the Method RELATEX." In: Schader, M. (Ed.): Analyzing and Modelling Data and Knowledge. Proceedings of the 15th Annual Conference of the "Gesellschaft für Klassifikation e.V.," University of Salzburg, February 25-27, 1991. Berlin, Heidelberg u.a., Springer-Verlag, 315-326.

SNell-Hornby, M. (21994/1986): Übersetzungswissenschaft—eine Neuorientierung. Zur Integrierung von Theorie und Praxis. Tübingen: Francke.

SowA, J. F. (1984): Conceptual Structures: Information processing in mind and machine. London: Addison-Wesley.

WiLss, W. (1977): Übersetzungswissenschaft. Probleme und Methoden. Stuttgart: Klett.

Wintermantel, M. (1998): "Gleiche Leistung-ungleiche Beurteilung? Effekte von Stereotypen auf die Urteilsbildung." In: Becker, E. D./Großmann, S./Jacobi, R./Sandig, B./Smaus, G./ Spangenberg, I./Wintermantel, M. (Hrsg.) (1998): Sofies Fächer. Wissenschaftlerinnen zu Frauenthemen. St. Ingbert: Röhrig. 155-181. 